\title{
THYROID HORMONES, INSULIN, BODY FAT, AND BLOOD BIOCHEMISTRY INDICES IN DAIRY COWS DURING THE REPRODUCTION/PRODUCTION CYCLE
}

\author{
Paulíková, I. ${ }^{1}$, Seidel, H. ${ }^{2}$, Nagy, O. ${ }^{1}$, Tóthová, Cs. ${ }^{1}$ \\ Konvičná, J. ${ }^{1}$, Kadaši, M. ${ }^{1}$, Kováč, G. ${ }^{1}$ \\ ${ }^{1}$ Clinic for Ruminants \\ ${ }^{2}$ Clinic for Swine, University of Veterinary Medicine and Pharmacy, Košice \\ Slovakia \\ iveta.paulikova@uvlf.sk
}

\section{ABSTRACT}

This study investigated the changes in: thyroid hormones, amount of subcutaneous fat, and selected indices of blood biochemistry in dairy cows in relation to the reproduction/production cycle. The blood samples were collected both ante- and post-partum every two weeks. When evaluating the mean values of the investigated indices, the major changes were recorded in dairy cows 3 to 14 days after calving. During this period, we observed a significant decrease in the mean serum levels of $\mathrm{T}_{3}(\mathrm{P}<0.05), \mathrm{T}_{4}(\mathrm{P}<0.01)$, and triglycerides $(\mathrm{P}<0.01)$. An opposite trend was observed with a significant increase after calving in the: mean serum levels of $\beta$-hydroxybutyrate $(\mathrm{P}<0.05)$, urea $(\mathrm{P}<0.01)$, and mean AST activities $(P<0.05)$. A significant increase over the normal range was recorded in the average levels of non-esterified fatty acids $(\mathrm{P}<0.01)$ and total bilirubin $(\mathrm{P}<0.01)$. From the next sampling $(28$ days after calving) onwards we recorded a significant increase in the blood serum levels of cholesterol $(\mathrm{P}<\mathbf{0 . 0 1})$, total lipids $(\mathrm{P}<0.01)$, total protein $(\mathrm{P}<0.01)$, as well as a significant decrease in the insulin levels $(\mathrm{P}<0.05)$ and a reduced layer of subcutaneous fat $(\mathrm{P}<0.01)$. The blood serum iodine concentration showed only slight significant changes $(\mathrm{P}<0.05)$ during the observation. Blood serum levels of glucose did not show any significant changes during the whole observation period. Within the whole observation period we found a negative correlation between $T_{3}$ levels and the layer of subcutaneous fat $(\mathrm{r}=-0.2606 ; \mathrm{P}<0.05)$. This correlation was much more marked in cows 3 to 14 days after calving $(\mathrm{r}=-0.5077 ; \mathrm{P}<0.05)$, which may indicate a possible relationships between the thyroid status, body condition, and post partum negative energy balance.

Key words: body fat volume; dairy cows; insulin; negative energy balance; thyroid

\section{INTRODUCTION}

The transitional period in dairy cows includes 3 weeks before and 3 weeks after calving, when the metabolic pro- 
cesses are adapting to provide energy and nutrients for the synthesis of milk compounds [15, 39].

During this period, the dairy cows undergo dramatic changes in lipid metabolism during the transition from gestation to lactation $[8,14]$. Even during ongoing lactation, homeostatic control of the metabolism varies markedly depending on the stage of lactation [8]. The post partum feeding pattern of nutrient intake does not keep up with the requirements. The peak milk production, at about 8 to 10 weeks post partum, occurs earlier than the maximum energy intake. Therefore, a negative energy balance (NEB) develops, most severely after parturition [14]. As a consequence, the body fat reserves are mobilized, resulting in elevated non-esterified fatty acids (NEFA) concentrations in the plasma [8]. These are taken up by the liver where they are either processed by the $\beta$-oxidation pathway or re-esterified to triglycerides (TG) and exported as very low-density lipoproteins (VLDL) [16). If the TG synthesis exceeds the TG export capabilities as VLDL, a fatty liver develops [16]. A fatty liver usually provokes other metabolic diseases and reproductive disorders that are initially derived from $\mathrm{NEB}$ during early lactation.

A negative energy balance in the transition period is the key factor determining the adaptation of a dairy cow's metabolism [17], including adaptation of the endocrine system, which is crucial to maintaining the metabolic balance [2]. The changes in the endocrine system affects predominately the glucose and lipid metabolism, to ensure the homeorhetic nutrient partitioning towards the prioritized mammary gland despite a catabolic state [14]. This selectivity in directing nutrients coincides with the reduced responsiveness and sensitivity of extrahepatic tissues to insulin, i.e. insulin resistance is thought to be markedly involved in developing ketosis and hepatic lipidosis [19].

Hormonal changes during the transition period are characterized by an increase in growth hormone and a decrease in insulin, thyroid hormones and insulin like growth factor (IGF-I) [30]. A positive correlation between circulating thyroid hormones and energy balance is well known in many species including cattle $[3,4,23,33,34,36]$.

The thyroid gland function and hormonal changes in the different reproductive periods in cows have been investigated by many authors $[1,37,48]$. The concentrations of thyroid hormones change significantly during the reproduction cycle. In accordance with the nutritional and metabolic processes during advanced pregnancy, dried cows showed high concentrations of thyroid hormones followed by a significant decrease in the peri partum period. Blood levels of thyroid hormones in peri partum cows decrease, particularly in early lactation, when the body reserves are mobilized for high milk production [21, 22, 25, 28, 44, 47, 48].

During post partum negative energy balance (NEB), dairy cows respond by lowering $\mathrm{T}_{3}$ and $\mathrm{T}_{4}$ and increasing $\mathrm{rT}_{3}$ concentrations $[35,42]$. Dairy cows in the first third of lactation showed low concentration of $\mathrm{T}_{3}$ and $\mathrm{T}_{4}$ [40], despite recovery of $\beta$-hydroxybutyrate $(\mathrm{BHB})$ and nonesterified fatty acids (NEFA) [12]. The concentrations of $\mathrm{T}_{3}$ and $\mathrm{T}_{4}$ correlate negatively with milk yield [48].

This study was aimed at the evaluation of energy metabolism, thyroid hormones, insulin, and body fat thickness in pre partum and post partum dairy cows.

\section{MATERIALS AND METHODS}

The experiments were carried out in accordance with the established standards for animal care and use on a farm near Košice. Dairy cows $(n=21)$ were in certain phases of ante partum (a.p.) and post partum (p.p.). The mean production age was 2.5 lactations ( $3-5$ years of age). The milk yield during the previous lactation was $6668.5 \mathrm{~kg}$ milk during a 305-day lactation. The animals were fed a total mix ration (TMR) twice daily, nutrient composition of the TMR varied with the stage of pregnancy and lactation (Table 1). The dairy cows had free access to drinking water.

Blood samples were collected by direct puncture of vena jugularis, $3 \mathrm{~h}$ after feeding, every two weeks (from the 6th week before expected calving until the 12th week after calving). In the blood serum we analysed the concentrations of: triiodothyronine $\left(\mathrm{T}_{3}\right)$, thyroxin $\left(\mathrm{T}_{4}\right)$, insulin, iodine (I), aspartate aminotransferase (AST), glucose (Glu), total protein (TP), urea (U), cholesterol (Chol), triglycerides (TG), total lipids (TL), non-esterified fatty acids (NEFA), $\beta$-hydroxybutyrate (BHB), and total bilirubin (TBil). The hormones $\mathrm{T}_{4}$ and $\mathrm{T}_{3}$ were determined by the ELISA method with the use of commercial ELISA kits (Human, Germany) and microtitration plates. The readings of absorbancies and calculations of the concentrations were done by automatic photometer Opsys MR (Dynex Technologies). The insulin (IU.ml ${ }^{-1}$ ) was determined by an ELISA method using a commercial assay (Cusabio, China) according to the manufacturer's instructions. The iodine 
Table 1. Components of pre partum (a.p.) and post partum (p. p.) diets [kg.head ${ }^{-1}$ day $\left.^{-1}\right]$

\begin{tabular}{lccccc}
\hline & $\begin{array}{c}\text { Weeks } \\
\mathbf{6 - 1} \\
\text { a.p. }\end{array}$ & $\begin{array}{c}\text { Week 1 } \\
\text { p.p. }\end{array}$ & $\begin{array}{c}\text { Week } 3 \\
\text { p.p. }\end{array}$ & $\begin{array}{c}\text { Week 6. } \\
\text { p.p. }\end{array}$ & $\begin{array}{c}\text { Week 9 } \\
\text { p.p. }\end{array}$ \\
\hline Meadow hay & 5.5 & 1.5 & 1.5 & 1.5 & 1.5 \\
R-24* & 0.3 & 0.25 & 0.3 & 0.25 & 0.25 \\
Haylage & 4 & 4 & 6 & 6 & 6 \\
Alfalfa silage & 13 & 24 & 22 & 22 & 22 \\
Green fodder & & 25 & 25 & 25 & 25 \\
Soybean meal & & 0.8 & 0.8 & & \\
Rape meal & & 2.5 & 2.5 & 2.5 & 2.5 \\
Wheat meal & & 3 & 4 & 2.5 & \\
Limestone & & 0.2 & 0.2 & 0.2 & 0.2 \\
Flaxseed & & & 0.5 & 1 & 1 \\
meal & & & & & \\
Maize meal & & & & & \\
Triticale & & & & & \\
\hline
\end{tabular}

${ }^{*} \mathrm{R}-24$ - mineral supplement $(10.4 \% \mathrm{Ca} ; 9 \% \mathrm{P} ; 11 \% \mathrm{Na} ; 4 \% \mathrm{Mg}$ $7000 \mathrm{mg} \mathrm{Cu} ; 3000 \mathrm{mg}$ inorganic $\mathrm{Mn} ; 6000 \mathrm{mg}$ inorganic Zn; $40 \mathrm{mg} \mathrm{Se}$; $100 \mathrm{mg} \mathrm{l} ; 20 \mathrm{mg} \mathrm{Co} ; 1000000$ IU vitamin A; 100000 IU vitamin D3;2000 IU vitamin E)

concentrations were estimated by a photometric method using a catalytic reaction $\mathrm{NO}_{2}^{-} / \mathrm{SCN}^{-}$[49]. The concentrations of: glucose, AST, TP, urea, Chol, TG, and BHB were determined by using commercial diagnostic kits (Randox, UK) on an automatic biochemical analyser Alizé (Lisabio, France). The concentrations of NEFA and TL (Randox, UK) were assessed by the spectrophotometric method Specord 210 Plus (Analytic Jena, Germany). The concentrations of total bilirubin were determined by a classic photometric method according to Jendrassik and Grof [24]. The backfat thickness (BFT) measurements were obtained by using a $3.5 \mathrm{MHz}$ linear transducer and were assessed according to Staufenbiel [45]. The examination site was located in the sacral region between the caudal one-quarter and one-fifth connection line going from the dorsal part of the tuber ischia (pins) to the tuber coxae (hooks). This site corresponds to the area between the end of the crista sacralis and the end of the os sacrum (i.e. beginning of the first coccygeal vertebra). Animals were scored for BFT on the day of their blood collection.
The evaluation of the results was performed by the assessment of the mean values ( $\mathrm{x}$ ) and standard deviations (SD) in each group of dairy cows. The significance of differences in the mean values in relation to the several monitored periods were evaluated by a one-way analysis of variance (ANOVA). The significance of differences in the mean values between groups was evaluated by Tukey's multiple comparisons test. The statistical analyses were done with the GraphPad Prism 3.0 software. The level of significance was set to $\mathrm{P}<0.05$, respectively.

\section{RESULTS}

The results of our investigation are presented in tables $2-16$. When evaluating the mean values of investigated indices, the major changes were recorded in dairy cows 3 to 14 days after calving. During this period, we observed a significant decrease in the mean serum levels of $\mathrm{T}_{3}(\mathrm{P}<0.05)$ and $\mathrm{T}_{4}(\mathrm{P}<0.01)$ (Tables 2, 3), a decrease in triglycerides $(\mathrm{P}<0.01)$ below the normal range (Table 4$)$, and a slight insignificant decrease in the mean serum cholesterol concentrations (Table 5).

An opposite trend, i.e. a significant increase after calving was found in the mean serum levels of $\beta$-hydroxybutyrate $(\mathrm{P}<0.05)$, urea $(\mathrm{P}<0.01)$, and mean AST activities $(\mathrm{P}<0.05)$ (Tables 6, 7, 8). A significant increase over the normal range was recorded in the average levels of non-esterified fatty acids $(\mathrm{P}<0.01)$ and total bilirubin $(\mathrm{P}<0.01)$ (Tables 9, 10).

From the next sampling (28 days after calving) onwards we recorded a significant increase in the blood serum levels of cholesterol $(\mathrm{P}<0.01)$ (Table 5$)$, total lipids $(\mathrm{P}<0.01)$ and total protein $(\mathrm{P}<0.01)$ (Tables 11,12$)$, as well as a significant decrease in the insulin levels $(\mathrm{P}<0.05)$ and reduced layer of subcutaneous fat $(\mathrm{P}<0.01)$ (Table 13, 14).

The blood serum iodine concentration showed only a slight significant change $(\mathrm{P}<0.05)$ during the observation (Table 15). The blood serum levels of glucose did not show any significant change during whole observation period (Table 16).

Within the whole observation period we found a significant negative correlation between $\mathrm{T}_{3}$ levels and layer of subcutaneous fat $(\mathrm{r}=-0.2606 ; \mathrm{P}<0.05)$. This correlation was much more marked in cows 3 to 14 days after calving $(\mathrm{r}=-0.5077 ; \mathrm{P}<0.05)$. 
Table 2. Mean blood serum $\mathrm{T}_{3}$ concentrations [ng. $\mathrm{ml}^{-1}$ ]

in dairy cows ante partum (a.p.) and post partum (p.p.)

\begin{tabular}{|c|c|c|c|c|c|c|c|c|c|}
\hline \multirow{2}{*}{ Sampling } & 1 & 2 & 3 & 4 & 5 & 6 & 7 & 8 & 9 \\
\hline & \multicolumn{9}{|c|}{ Days 3-14 p.p. } \\
\hline$x$ & 2.00 & 1.88 & $2.03^{a}$ & $1.55^{\mathrm{b}, \mathrm{c}}$ & 1.98 & 2.00 & $2.11 \underline{\mathrm{d}}$ & 1.92 & 1.82 \\
\hline$\pm \mathrm{SD}$ & 0.232 & 0.377 & 0.218 & 0.352 & 0.391 & 0.48 & 0.536 & 0.398 & 0.572 \\
\hline ANOVA & 0.0051 & & & & & & & & \\
\hline
\end{tabular}

Table 3. Mean blood serum T4 concentrations [ $\mu \mathrm{g} . \mathrm{dl}^{-1}$ ]

in dairy cows a.p. and p.p.

\begin{tabular}{cccccccccc}
\hline \multirow{2}{*}{ Sampling } & $\mathbf{1}$ & $\mathbf{2}$ & $\mathbf{3}$ & $\mathbf{4}$ & $\mathbf{5}$ & $\mathbf{6}$ & $\mathbf{7}$ & $\mathbf{8}$ & $\mathbf{9}$ \\
\cline { 2 - 10 } & \multicolumn{8}{c}{ Days 3-14 p.p. } \\
\hline $\mathrm{X}$ & $6.82^{\mathrm{e}}$ & $7.01^{\mathrm{a}, \mathrm{g}}$ & 5.78 & $4.75^{\mathrm{c}, \mathrm{f}, \mathrm{h}}$ & $5.13^{\mathrm{b}}$ & 5.41 & 5.86 & $6.26^{\mathrm{d}}$ & 5.77 \\
$\pm \mathrm{SD}$ & 0.496 & 1.019 & 0.885 & 1.381 & 1.117 & 0.63 & 1.293 & 1.216 & 1.46 \\
\hline ANOVA & $\mathbf{0 . 0 0 0 1}$ & & &
\end{tabular}

a, bic,d - values with the superscripts differ at $P<0.05^{;}{ }^{e, f_{i} g, h}-$ values with the superscripts differ at $P<0.01$

Table 4. Mean blood serum triglycerides concentrations [mmol. $\left.\mathrm{I}^{-1}\right]$ in dairy cows a.p. and p.p.

\begin{tabular}{|c|c|c|c|c|c|c|c|c|c|}
\hline \multirow{2}{*}{ Sampling } & 1 & 2 & 3 & 4 & 5 & 6 & 7 & 8 & 9 \\
\hline & \multicolumn{9}{|c|}{ Days 3-14 p.p. } \\
\hline$x$ & 0.217 & $0.273^{\mathrm{a}}$ & $0.265^{e}$ & $0.135^{b, f, g}$ & $0.281^{\mathrm{h}}$ & $0.345^{c, h}$ & $0.285^{\mathrm{h}}$ & $0.231^{d}$ & $0.206^{d}$ \\
\hline $\pm S D$ & 0.074 & 0.085 & 0.084 & 0.055 & 0.169 & 0.109 & 0.091 & 0.031 & 0.037 \\
\hline ANOVA & 0.0001 & & & & & & & & \\
\hline
\end{tabular}

Table 5. Mean blood serum cholesterol concentrations [mmol. $\left.\mathrm{I}^{-1}\right]$ in dairy cows a.p. and p.p.

\begin{tabular}{|c|c|c|c|c|c|c|c|c|c|}
\hline \multirow{2}{*}{ Sampling } & 1 & 2 & 3 & 4 & 5 & 6 & 7 & 8 & 9 \\
\hline & \multicolumn{9}{|c|}{ Days 3-14 p.p. } \\
\hline$x$ & $2.6^{e}$ & $2.8^{g}$ & $2.2^{i}$ & $2.2^{\mathrm{d}, \mathrm{k}}$ & $3.3^{b, c, m}$ & $4.7^{f, h, j, l, n}$ & $4.8^{f, h, j, l, n}$ & $5.6^{f, h, j, l, n}$ & $4.7^{d, f, h, j, l, n}$ \\
\hline $\pm S D$ & 0.35 & 0.59 & 0.30 & 0.51 & 0.86 & 0.98 & 1.37 & 1.54 & 0.78 \\
\hline ANOVA & 0.0001 & & & & & & & & \\
\hline
\end{tabular}

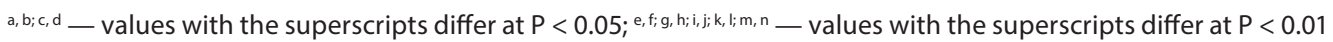


Table 6. Mean blood serum BHB concentrations [mmol. $\left.\mathrm{I}^{-1}\right]$ in dairy cows a.p. and p.p.

\begin{tabular}{|c|c|c|c|c|c|c|c|c|c|}
\hline \multirow{2}{*}{ Sampling } & 1 & 2 & 3 & 4 & 5 & 6 & 7 & 8 & 9 \\
\hline & \multicolumn{9}{|c|}{ Days 3-14 p.p. } \\
\hline $\mathbf{x}$ & 0.355 & 0.429 & 0.429 & 0.762 & 0.794 & 0.554 & 0.514 & 0.418 & 0.506 \\
\hline \pm SD & 0.044 & 0.15 & 0.094 & 0.285 & 0.927 & 0.292 & 0.257 & 0.196 & 0.134 \\
\hline ANOVA & 0.035 & & & & & & & & \\
\hline
\end{tabular}

Table 7. Mean blood serum urea concentrations $\left[\mathrm{mmol} . \mathrm{I}^{-1}\right]$ in dairy cows a.p. and p.p.

\begin{tabular}{cccccccccc}
\hline \multirow{2}{*}{ Sampling } & $\mathbf{1}$ & $\mathbf{2}$ & $\mathbf{3}$ & $\mathbf{4}$ & $\mathbf{5}$ & $\mathbf{6}$ & $\mathbf{7}$ & $\mathbf{8}$ & $\mathbf{9}$ \\
\cline { 2 - 9 } & \multicolumn{8}{c}{ Days 3-14 p.p. } \\
\hline $\mathrm{x}$ & $2.2 \mathrm{a}$ & $2.3 \mathrm{c}$ & $2.7 \mathrm{e}$ & $4.6 \mathrm{~b}, \mathrm{~d}, \mathrm{f}$ & $4.9 \mathrm{~b}, \mathrm{~d}, \mathrm{f}$ & $5.7 \mathrm{~b}, \mathrm{~d}, \mathrm{f}$ & $5.2 \mathrm{~b}, \mathrm{~d}, \mathrm{f}$ & $4.9 \mathrm{~b}, \mathrm{~d}, \mathrm{f}$ & $4.2 \mathrm{~b}, \mathrm{~d}, \mathrm{f}$ \\
$\pm \mathrm{SD}$ & 0.73 & 0.63 & 0.84 & 1.87 & 1.27 & 1.24 & 1.19 & 0.97 & 0.90 \\
\hline ANOVA & $\mathbf{0 . 0 0 1 1}$ & & \multicolumn{10}{c}{} \\
\hline
\end{tabular}

$a, b ; c, d ; e, f-$ values with the superscripts differ at $P<0.01$

Table 8. Mean blood serum AST activities [ $\mu$ kat..$\left.^{-1}\right]$ in dairy cows a.p. and p.p.

\begin{tabular}{|c|c|c|c|c|c|c|c|c|c|}
\hline \multirow{2}{*}{ Sampling } & 1 & 2 & 3 & 4 & 5 & 6 & 7 & 8 & 9 \\
\hline & \multicolumn{9}{|c|}{ Days 3-14 p.p. } \\
\hline$x$ & 1.35 & $1.19 a$ & $1.19 c$ & $1.74 b, d$ & 1.54 & 1.54 & 1.58 & 1.41 & 1.40 \\
\hline $\pm S D$ & 0.221 & 0.135 & 0.205 & 0.477 & 0.358 & 0.509 & 0.466 & 0.197 & 0.166 \\
\hline ANOVA & 0.002 & & & & & & & & \\
\hline
\end{tabular}

a, b - values with the superscripts differ at $P<0.05 ; c, d-$ values with the superscripts differ at $P<0.01$

Table 9. Mean blood serum NEFA concentrations [mmol. $\left.\mathrm{I}^{-1}\right]$ in dairy cows a.p. and p.p.

\begin{tabular}{cccccccccc}
\hline \multirow{2}{*}{ Sampling } & $\mathbf{1}$ & $\mathbf{2}$ & $\mathbf{3}$ & $\mathbf{4}$ & $\mathbf{5}$ & $\mathbf{6}$ & $\mathbf{7}$ & $\mathbf{8}$ & $\mathbf{9}$ \\
\cline { 2 - 9 } & \multicolumn{8}{c}{ Days 3-14 p.p. } \\
\hline $\mathrm{X}$ & $0.347^{\mathrm{a}}$ & $0.513^{\mathrm{c}}$ & $0.595^{\mathrm{e}}$ & $1.566^{\mathrm{b}, \mathrm{d}, \mathrm{f}, \mathrm{g}}$ & $0.941^{\mathrm{h}}$ & 0.815 & $0.702^{\mathrm{h}}$ & $0.632^{\mathrm{h}}$ & $0.406^{\mathrm{h}}$ \\
$\pm \mathrm{SD}$ & 0.102 & 0.22 & 0.264 & 0.63 & 0.397 & 0.394 & 0.282 & 0.393 & 0.111 \\
\hline ANOVA & $\mathbf{0 . 0 0 0 1}$ & & & & \\
\hline
\end{tabular}

$a, b ; c, d ; e, f ; g, h-$ values with the superscripts differ at $P<0.01$

Table 10. Mean blood serum total bilirubin concentrations $\left[\mu \mathrm{mol} . \mathrm{I}^{-1}\right]$ in dairy cows a.p. and p.p.

\begin{tabular}{|c|c|c|c|c|c|c|c|c|c|}
\hline \multirow{2}{*}{ Sampling } & 1 & 2 & 3 & 4 & 5 & 6 & 7 & 8 & 9 \\
\hline & \multicolumn{9}{|c|}{ Days 3-14 p.p. } \\
\hline$x$ & $4.67^{a}$ & $5.10^{c}$ & $5.06^{e}$ & $9.85^{b, d, f, g}$ & 7.36 & $5.98^{h}$ & $5.94^{h}$ & $5.49^{h}$ & $4.86^{h}$ \\
\hline $\pm S D$ & 0.542 & 1.036 & 1.107 & 4.484 & 4.621 & 1.26 & 1.355 & 1.618 & 1.187 \\
\hline ANOVA & 0.0001 & & & & & & & & \\
\hline
\end{tabular}


Table 11. Mean blood serum total lipid concentrations [g. $\left.\mathbf{I}^{-1}\right]$

in dairy cows a.p. and p.p.

\begin{tabular}{|c|c|c|c|c|c|c|c|c|c|}
\hline \multirow{2}{*}{ Sampling } & 1 & 2 & 3 & 4 & 5 & 6 & 7 & 8 & 9 \\
\hline & \multicolumn{9}{|c|}{ Days 3-14 p.p. } \\
\hline$x$ & $3.95^{a, g}$ & $3.9^{c, e, i}$ & $3.7^{\mathrm{k}}$ & $4.1^{\mathrm{m}}$ & $5.4^{\mathrm{d}, \mathrm{o}}$ & $7.1^{h, j, l, n, p}$ & $6.9^{h, j, l, n, p}$ & $6.5^{h, j, l, n, p}$ & $5.7^{b, f, l, n}$ \\
\hline $\pm S D$ & 0.301 & 0.24 & 0.21 & 0.722 & 1.449 & 1.04 & 1.4 & 0.624 & 0.732 \\
\hline ANOVA & 0.0001 & & & & & & & & \\
\hline
\end{tabular}

Table 12. Mean blood serum total protein concentrations $\left[g . I^{-1}\right]$ in dairy cows a.p. and p.p.

\begin{tabular}{|c|c|c|c|c|c|c|c|c|c|}
\hline \multirow{2}{*}{ Sampling } & 1 & 2 & 3 & 4 & 5 & 6 & 7 & 8 & 9 \\
\hline & \multicolumn{9}{|c|}{ Days 3-14 p.p. } \\
\hline$x$ & $72.0^{\mathrm{a}}$ & $72.6^{e}$ & $71.3^{c, g}$ & $75.1^{i}$ & 79.3 & $79.8^{d}$ & $81.6^{h}$ & $84.1^{b, f, h, j}$ & $81.8^{d}$ \\
\hline $\pm S D$ & 11.96 & 5.69 & 4.77 & 6.15 & 6.40 & 5.558 & 6.96 & 7.76 & 7.50 \\
\hline ANOVA & 0.001 & & & & & & & & \\
\hline
\end{tabular}

${ }_{a}, b ; c, d$ - values with the superscripts differ at $P<0.05 ;{ }^{e, f ; g, h ; i, j}-$ values with the superscripts differ at $P<0.01$

Table 13. Mean blood serum insulin concentrations [IU.ml-1] in dairy cows a.p. and p.p.

\begin{tabular}{|c|c|c|c|c|c|c|c|c|c|}
\hline \multirow{2}{*}{ Sampling } & 1 & 2 & 3 & 4 & 5 & 6 & 7 & 8 & 9 \\
\hline & \multicolumn{9}{|c|}{ Days 3-14 p.p. } \\
\hline$x$ & 589.8 & 577.6 & 616.0 & 624.4 & 654.3 & 353.9 & 394.6 & 374.9 & 392.9 \\
\hline $\pm S D$ & 94.1 & 37.8 & 181.5 & 553.7 & 575.1 & 115.5 & 155.9 & 157.8 & 128.5 \\
\hline ANOVA & 0.0434 & & & & & & & & \\
\hline
\end{tabular}

Table 14. Mean thickness of subcutaneous fat [cm] in dairy cows a.p. and p.p.

\begin{tabular}{|c|c|c|c|c|c|c|c|c|c|}
\hline \multirow{2}{*}{ Sampling } & 1 & 2 & 3 & 4 & 5 & 6 & 7 & 8 & 9 \\
\hline & \multicolumn{9}{|c|}{ Days 3-14 p.p. } \\
\hline $\mathrm{x}$ & $3.30^{\mathrm{a}}$ & $3.39^{e}$ & 3.45 & $3.02^{c, g}$ & $2.50^{f}$ & $2.35^{b, d, f}$ & $2.35^{\mathrm{b}, \mathrm{f}, \mathrm{h}}$ & 2.39 & 2.41 \\
\hline $\pm S D$ & 1.025 & 0.555 & 0.092 & 0.491 & 0.513 & 0.404 & 0.318 & 0.226 & 0.253 \\
\hline ANOVA & 0.0001 & & & & & & & & \\
\hline
\end{tabular}

${ }_{a}, b ; c, d-$ values with the superscripts differ at $P<0.05 ;{ }^{e, f ; g, h}$ - values with the superscripts differ at $P<0.01$ 
Table 15. Mean blood serum iodine concentrations [ $\left.\mu \mathrm{g} . \mathrm{I}^{-1}\right]$

in dairy cows a.p. and p.p.

\begin{tabular}{|c|c|c|c|c|c|c|c|c|c|}
\hline \multirow{2}{*}{ Sampling } & 1 & 2 & 3 & 4 & 5 & 6 & 7 & 8 & 9 \\
\hline & \multicolumn{9}{|c|}{ Days 3-14 p.p. } \\
\hline$x$ & 55.30 & 55.55 & 56.21 & 56.43 & 53.57 & 51.65 & 52.18 & 51.82 & 52.30 \\
\hline$\pm \mathrm{SD}$ & 3.83 & 6.191 & 4.224 & 10.013 & 3.287 & 1.622 & 2.011 & 1.611 & 0.526 \\
\hline ANOVA & 0.0401 & & & & & & & & \\
\hline
\end{tabular}

Table 16. Mean blood serum glucose concentrations [mmol. $\mathrm{I}^{-1}$ ] in dairy cows a.p. and p.p.

\begin{tabular}{|c|c|c|c|c|c|c|c|c|c|}
\hline \multirow{2}{*}{ Sampling } & 1 & 2 & 3 & 4 & 5 & 6 & 7 & 8 & 9 \\
\hline & \multicolumn{9}{|c|}{ Days 3-14 p.p. } \\
\hline$x$ & 3.98 & 3.92 & 3.85 & 3.64 & 3.77 & 3.95 & 3.82 & 3.85 & 3.56 \\
\hline $\pm S D$ & 0.128 & 0.195 & 0.245 & 0.966 & 0.413 & 0.425 & 0.344 & 0.301 & 0.213 \\
\hline ANOVA & n.s. & & & & & & & & \\
\hline
\end{tabular}

n.s. - non-significant

\section{DISCUSSION}

Within our observations, the indices of energy and lipid metabolism corresponded to the well-known findings reported in fresh cows $[2,8,9,13,14,16]$.

The blood serum levels of glucose, which are considered to be a direct indicator of energy balance [38], did not show any significant changes during the entire observation period. However, a more reliable indicator of the cow's energy status is the concentration of $\beta$-hydroxybutyrate [41, 46]. Within our observations, a decrease in triglycerides $(\mathrm{P}<0.01)$ below the normal range, as well as an increase in the mean serum levels of $\beta$-hydroxybutyrate $(P<0.05)$, and non-esterified fatty acids $(\mathrm{P}<0.01)$ in dairy cows 3 to 14 days after calving indicated some degree of negative energy balance.

The negative energy balance in the transition period is the key factor determining adaptation of a dairy cow's metabolism [17], including adaptation of the endocrine system, which is crucial in order to maintain the metabolic balance [2]. Hormonal changes in the transition period are characterized by an increase in growth hormone and a decrease in insulin, thyroid hormones and insulin like growth factor (IGF-I) [31]. A similar decrease in the mean serum insulin and thyroid hormones was observed also in our observation. The level of insulin in bovine serum strongly correlates with the body weight increase rate $[11,18,20]$ and limited feed intake by the animals results in a decrease in the content of insulin in blood serum [53]. A decrease in insulin after calving is probably related to inappetence, which is typical during the periparturient period [9]. The plasma insulin is additionally known to suppress lipolysis from adipose tissues [19]. However, the plasma insulin concentration in dairy cows is decreased after parturition and enables, along with concomitant insulin resistance and the associated loss of inhibitory effects on lipolysis, the high degree of metabolic priority [14].

Limited food energy content decreases also the serum levels of triiodothyronine $\left(\mathrm{T}_{3}\right)$ and thyroxin $\left(\mathrm{T}_{4}\right)$ [11]. The thyroid hormones are of importance in adapting the endocrine system during lactation, since their very low blood levels in peri-partal cows leads to a decrease in energy metabolism, mobilization of body fat reserves and their partitioning towards high milk production $[21,29,48]$.

Periparturient hormonal changes including thyroid hormones and their relation to lipid metabolism and body condition has been studied by many authors $[5,6,7,10,17$, $26,27,31,32,50]$.

Kapp et al. [26] suggested an important role of an endocrine disorder, particularly thyroid, in the pathogenesis of liver steatosis in high-yielding Holstein-Friesian dairy 
cows. The authors consider "fatty liver" syndrome as a consequence of hypothyreoidosis, when insufficient thyroid function (low serum levels of $\mathrm{T}_{4}$ and $\mathrm{T}_{3}$ ) leads to endocrine dysfunctions, liver disorders and frequent puerperal complications.

A decrease in circulating $\mathrm{T}_{4}$ and $\mathrm{T}_{3}$ hormones and functionless thyroid hypertrophy was observed in dairy cows suffering from adipose-hepatic fat syndrome. Presumably, there is protein-energy (or another) deficiency accompanied by obesity [27]. This syndrome is associated with hormonal imbalance and metabolic disorders followed by reproduction disorders (stillbirths, retained placenta, metritis, low fertility).

Durdevič et al. [10] compared $\mathrm{T}_{4}$ and $\mathrm{T}_{3}$ levels in the blood serum of cows with and without ketosis. In dairy cows with ketosis they found significantly lower hormone levels: $\mathrm{T}_{4} 0.7 \pm 0.4$ vs. $3.6 \pm 1.1 \mu \mathrm{g} . \mathrm{dl}^{-1} ; \mathrm{T}_{3} 0.83 \pm 0.22$ vs. $1.22 \pm 0.23$ ng. $\mathrm{ml}^{-1}$. Similarly, Djokovič et al. [7] studied the blood concentrations of thyroid hormones, lipids, glucose, and liver lipid content in dairy cows during the transitional period. In ketotic dairy cows, they suggested established a hypothyroidal status. Kostopanagiotou et al. [32] reported during acute liver failure markedly decreased serum thyroxin $\left(\mathrm{T}_{4}\right)$ and triiodothyronine $\left(\mathrm{T}_{3}\right)$ levels, whereas free-triiodothyronine and thyroxin-stimulating hormone levels did not change. $\mathrm{T}_{4}$ and $\mathrm{T}_{3}$ levels correlated with the degree of liver failure. Gvozdič et al. [17] reported significantly lower thyroid hormone levels in obese cows. Over conditioned dry dairy cows showed also decreased insulin sensitivity and decreased insulin responsiveness of the glucose metabolism [6], which may contribute to lipomobilisation level.

\section{List of abbreviations}

$\begin{array}{ll}\text { ANOVA } & \text { analysis of variance } \\ \text { a.p. } & \text { ante-partum (pre-partum) } \\ \text { AST } & \text { aspartate aminotransferase } \\ \text { BFT } & \text { backfat thickness } \\ \text { BHB } & \text { B-hydroxybutyrate } \\ \text { Glu } & \text { glucose } \\ \text { I } & \text { iodine } \\ \text { IGF-I } & \text { insulin like growth factor } \\ \text { p.p. } & \text { post-partum } \\ \mathrm{T}_{3} & \text { triiodothyronine } \\ \mathrm{T}_{4} & \text { thyroxin }\end{array}$

These data indicate an association between thyroid status, level of lipomobilisation and body condition, respectively. Within all of our observation period, we found a significant negative correlation between $\mathrm{T}_{3}$ levels and the layer of subcutaneous fat $(\mathrm{r}=-0.2606 ; \mathrm{P}<0.05)$. This correlation was much more marked in cows 3 to 14 days after calving $(\mathrm{r}=-0.5077 ; \mathrm{P}<0.05)$. However, there is a question of what is primary and what is secondary - low thyroid status or over conditioning. It is well known that hypothyroidism causes a weight increase together with a decrease in basal metabolic rate $[43,52]$. On the other side, obesity also contributes to thyroid dysfunction in a form of mildly elevated TSH levels [51].

\section{CONCLUSIONS}

Within our observations, the indices of energy and lipid metabolism indicate some degree of negative energy balance and corresponds to well-known findings reported in fresh cows. The analyses of thyroid hormones and back fat thickness indicate an association between thyroid status, body fat volume, degree of negative energy balance, and the level of lipomobilisation. However, the cause of lower thyroid status in cows with subcutaneous fat needs to be clarified.

\section{ACKNOWLEDGEMENT}

This study was supported by VEGA scientific grant No. 1/0203/15 of the Ministry of Education of SR.

$\begin{array}{ll}\text { TBil } & \text { total bilirubin } \\ \text { TG } & \text { triglycerides } \\ \text { TL } & \text { total lipids } \\ \text { TMR } & \text { total mix ration } \\ \text { TP } & \text { total protein } \\ \text { NEB } & \text { negative energy balance } \\ \text { NEFA } & \text { non-esterified fatty acids } \\ \text { SD } & \text { standard deviation } \\ \text { U } & \text { urea } \\ \text { VLDL } & \text { very low-density lipoproteins } \\ \mathrm{x} & \text { mean value }\end{array}$




\section{REFERENCES}

1. Aceves, C., Ruiz, A., Romero, C., Valverde, C., 1985: Homeorhesis during early lactation. Euthyroid sick-like syndrome in lactating cows. Acta Endocrinol. (Copenh.), 110, 505-509.

2. Bauman, D. E., Currie, W. B., 1980: Partitioning of nutrients during pregnancy and lactation - A review of mechanisms involving homeostasis and homeorhesis. J. Dairy Sci., 63, 1514-1518.

3. Capuco, A.V., Wood, D.L., Elsasser, T.H., Kahl, S., Erdman, R.A., Van Tasel, C.P. et al., 2001: Effect of somatotropin on thyroid hormones and cytokines in lactating dairy cows during ad libitum and restricted feed intake. J. Dairy Sci., $84,2430-2439$.

4. Cassar-Malek, I., Kahl, S., Jurie, C., Picard, C., 2001: Influence of feeding level during postweaning growth on circulating concentrations of thyroid hormones and extrathyroidal 5'-deiodination in steers. J. Anim. Sci., 79, 2679-2687.

5. Celeska, I., Ulčar, I., Dovenski, T., Mitrov, D., Džadžovski, I., Kuzmanovska, S., 2011: Correlation between thyroid status and some biochemical parameters of dairy cows in different stages of lactation. Veterinarska Stanica, 42 (Supplement 1), 173.

6. De Koster, J., Hostens, M., Van Eetvelde, M., Hermans, K., Moerman, S., Bogaert, H. et al., 2015: Insulin response of the glucose and fatty acid metabolism in dry dairy cows across a range of body condition scores. J. Dairy Sci., 98, 4580-4592.

7. Djokovič, R., Šamanc, H., Jovanovič, M., Nikolič, Z., 2007: Blood concentrations of thyroid hormones and lipids and content of lipids in the liver in dairy cows in transitional period. Acta Vet. Brno, 76, 525-532.

8. Drackley, J. K, 1999: ADSA Foundation Scholar Award, Biology of dairy cows during the transition period: the final frontier? J. Dairy Sci., 82, 2259-2273.

9. Drackley, J.K., Dann, H.M., Douglas, G.N., Janovick Guretzky, N. A., Litherland, N. B., Underwood, J.P. et al., 2005: Physiological and pathological adaptations in dairy cows that may increase susceptibility to periparturient diseases and disorders. Ital. J. Anim. Sci., 4, 323-344.

10. Durdevič, D., Stojič, V., Jovanovič, M.J., Radakovič, N., 1980: Concentration of thyroxine, triiodothyronine and cortisol in the blood serum of ketotic cows. Acta Vet. Beograd, 30, $7-12$.

11. Ellenberger, M. A., Johnson, D. E., Carstens, G. E., Hossner,
K. L., Holland, M. D, Nett, T. M. et al., 1989: Endocrine and metabolic changes during altered growth rates in beef cattle. J. Anim. Sci., 67, 1446-1454.

12. Eppinga, M., Suriyasathaporn, W., Kulcsar, M., Huszenica, G. Y., Wensing, T., Dieleman, S. J., 1999: Thyroxin and triiodothyronine in association with milk yield, $\beta \mathrm{OH}$-butyrate, and non-esterified fatty acid during the peak of lactation. Abstract. J. Dairy Sci., 82, 50.

13. Gross, J. J., Kessler, E. C., Albrecht, C. H., Brukmaier, R. M., 2015: Response of the cholesterol metabolism to a negative energy balance in dairy cows depends on the lactational stage. http://dx.doi.org/10.1371/journal.pone.0121956.

14. Gross, J., Van Dorland, H. A., Bruckmaier, R. M., Schwarz, F. J., 2011: Performance and metabolic profile of dairy cows during a lactational and deliberately induced negative energy balance by feed restriction with subsequent realimentation. J. Dairy Sci., 94, 1820-1830.

15. Grummer, R. R., 1995: Impact of changes in organic nutrient metabolism on feeding the transition dairy cows. J. Anim. Sci., 73, 2820-2833.

16. Grummer, R. R., 1993: Etiology of lipid-related metabolic disorders in periparturient dairy cows. J. Dairy Sci., 76, 38823896.

17. Gvozdić, D., Stojić, V., Šamanc, H., Dorić, G., Vujanac, I., 2006: Thyroid gland status and body condition score (BCS) in peripartal dairy cows. Slov. Vet. Res., Suppl. 43, 98-99.

18. Hayden, I. M., Williams, J.E., Collier, J. J., 1993: Plasma growth hormone, insulin-like growth factor, insulin, and thyroid hormone association with body protein and fat accretion in steers undergoing compensatory gain after dietary energy restriction. J. Anim. Sci., 71, 3327-3338.

19. Hayrili, A., 2006: The role of oxygenous insulin in the complex of hepatic lipidosis and ketosis associated with insulin resistance phenomenon in post partum dairy cows. Vet. Res. Commun., 30, 749-774.

20. Hersom, M. J., Wettman, R. P., Krehbiel, C. R., Horn, G. W., Keisler, D. H., 1993: Blood metabolites and hormones during winter grazing: III. Blood metabolites and hormones during feedlot finishing. J. Anim. Sci., 82, 2059-2068.

21. Huszenica, G. Y., Kulcsar, M., Rudas, P., 2002: Clinical endocrinology of thyroid gland function in ruminants: A review of literature. Vet. Med., 47, 191-202.

22. Huszenica, G. Y., Kulcsar, M., Nikolič, J. A., Schmidt, J., Korodi, P., Katai, L. et al., 2001: Plasma leptin concentration and its interrelation with some blood metabolites, metabolic hormones and the resumption of cyclic ovarian function in 
post partum dairy cows supplemented with monensin or inert fat in feed. In Diskin, M.G. (Ed.): Fertility in the Highproducing Dairy Cow. British Society of Animal Science. Edinburgh, Occasional Publications, 2, 405-409.

23. Janam, J., Rudas, P., Bartha, T., Bozó, S., Gábor, G. Y., 1995: Effect of severe energy restriction and refeeding on thyroid hormones in bulls. Acta Vet. Hungarica, 43, 173-177.

24. Jendrassik, L., Grof, P., 1938: Vereinfachte photometrische Methoden zur Bestimmung des Blutbilirubins. Biochem. Z., 297, 81-89.

25. Jovanović, M., Stojić, V., Djurdević. D., Sinadinović, J., 1988: Puerperal changes of thyroxine and triiodothyronine serum levels in dairy cows. In Book of Abstracts of the XIXth Annual Meeting of ESNA, 111.

26. Kapp, P., Pethes, G., Zsíros, M., Schuster, Z., 1978: Hypothyreogenic fatty liver syndrome in high-yielding dairy cows (In Hungarian). Magyar Állat. Lapja, 10, 653-654.

27. Kapp, P., Pethes, G., Zsíros, M., Schuster, Z., 1979: Contribution to pathogenesis of fatty liver syndrome in highyielding dairy cows (In Hungarian). Magyar Állat. Lapja, 34, $458-469$.

28. 28. Kesler, D. J., Johnson, H. D., Garverick, H. A., 1981: Post partum concentrations of thyroxin in plasma of dairy cows. J. Dairy Sci., 64, 1618-1620.

29. Khatri, P., Bhutto, B., 2014: Expression of androgen receptors at mRNA level in bovine placentomes during 50-150 days of pregnancy. Pak. J. Agri. Sci., 51, 303-307.

30. Kirovski, D., Sladojević, Ž., Stojić, V., Vujanac, I., Lazarević, I., Radovanović, A. et al., 2012: Effect of peri partum dietary energy supplementation on thyroid hormones, insulin-like growth factor-I and its binding proteins in early lactation dairy cows. Acta Vet. (Beograd), 62, 403-419.

31. Kirovski, D., Šamanc, H., Stojić, V., Vujanać, M., Jovanović, M., Prodanović, R., 2011: The use of thyroid status of mid dry dairy cows for the prediction of postpartal fatty liver. Veterinarska Stanica, 42 (Supplement 1), 57.

32. Kostopanagiotou, G., Kalimeris, K., Mourouzis, I., Costopanagiotou, C., Arkadopoulos, N., Panagopoulos, D. et al., 2009: Thyroid hormones alterations during acute liver failure: possible underlying mechanisms and consequences. Endocrine, 36, 198-204.

33. Kunz, P. L., Blum, J. W., 1985: Relationships between energy balances and blood levels of hormones and metabolites in dairy cows during late pregnancy and early lactation. J. Anim. Physiol. Anim. Nutr., 54, 239-248.

34. Leyva-Ocariz, H., Lucciola, K., Puzzar, S., 1997: Serum thy- roid hormone concentrations during growth and puberty in Carora dairy heifers of Venezuela. Theriogenology, 48, 19-31.

35. McGuire, M. A., Beede, D. K., Collier, R. J., Buonomo, F. C., De Lorenzo, M. A., Wilcox, C. J., 1991: Effects of acute thermal stress and amount of feed intake on concentrations of somatotropin insulin-like growth factor (IGF)-I and IGF-II, and thyroid hormones in plasma of lactating Holstein cows. J. Anim. Sci., 69, 2050-2056.

36. Nikolič, J. A., Šamanc, H., Begovic, J., Damjanovic, Z., Dokovic, R., Kostic, G. et al., 1997: Low peripheral serum thyroid hormone status independently affects the hormone profiles of healthy and ketotic cows during the first post partum. Acta Vet. (Beograd), 47, 3-14.

37. Nixon, D. A., Akasha, M. A., Anderson, R. R., 1988: Free and total thyroid hormones in serum of Holstein cows. J. Dairy Sci., 71, 1152-1160.

38. Oler, A., Glovinska, B., 2013: Blood chemistry, thyroid hormones, and insulin serum content in bulls fed a ration limited in energy. Turk. J. Vet. Anim. Sci., 37, 194-199.

39. Overton, T.R., Waldron, M.R., 2004: Nutritional management of transition dairy cows: Strategies to optimize metabolic health. J. Dairy Sci., 87, E105-E119.

40. Pethes, G. Y., Bokori, J., Rudas, P., Frenyó, V.L., Fekete, S., 1985: Thyroxine, triiodothyronine, reverse-triiodothyronine and other physiological characteristics of periparturient cows fed restricted energy. J. Dairy Sci., 68, 1148-1154.

41. Prodanovič, R., Kirovski, D., Jakič-Dimič, D., Vujanac, I., Kureljušič, B., 2010: Body conditions and indicators of energy status in cows in late pregnancy and early lactation stage. Veterinarski Glasnik, 63, 43-52.

42. Ronge, H., Blum, J., Clement, C., Jans, F., Leuenberger, H., Binder, H., 1988: SomatomedinC in dairy cows related to energy and protein supply and to milk production. Anim. Prod., 47, 165-183.

43. Seppel, T., Kosel, A., Schlaghecke, R., 1997: Bioelectric impedance assessment of body composition in thyroid disease. Eur. J. Endocrinol., 136, 493-498.

44. Sinka, K., Illek, J., Kumprechtová, D., Novák, P., 2008: Changes in $\mathrm{T}_{3}$ and $\mathrm{T}_{4}$ plasma concentrations in dairy cows during lactation. Jubilee World Buiatrics Congress, July 6-11, Budapest, Hungary, 283.

45. Staufenbiel, R., 1997: Condition assessment of dairy cows using the ultrasound backfat thickness measurement (In German). Pract. Veterinary Coll. Vet., 27, 8792.

46. Stengärde, L., Traven, M., Emanuelson, U., Holtenius, K., Hultgren, J., Niskanen, R., 2008: Metabolic profiles in five 
high-producing Swedish dairy herds with a history of abomasal displacement and ketosis. Acta Vet. Scand., 50, 31.

47. Stojić, V., Gvozdić, D., Kirovski, D., Nikolić, J., Huszenica, G. Y., Šamanc, H. et al., 2001: Serum thyroxine and triiodothyronine concentrations prior to and after delivery in primiparous Holstein cows. Acta Vet. Beograd, 51, 3-8.

48. Tiirats, T., 1997: Thyroxine, triiodothyronine concentrations in blood plasma in relation to lactational stage, milk yield, energy and dietary protein intake in Estonian dairy cows. Acta Vet. Scand., 38, 339-348.

49. Tušl, J., 1983: Photometrical determination of traces of iodine in food based on catalytic reaction NO-2/SCN (In Czech). Chemické listy (Chemical letters), 7, 513-515.

50. Vargová, M., Petrovič, V., Konvičná, J., Kadaši, M., Zaleha, P., Kováč, G., 2015: Hormonal profile and body condition scoring in dairy cows during pre partum and post partum periods. Acta Vet. Brno, 28, 141-151.
51. Verma, A., Jayaraman, M., Kumar, H. K. V. S., Modi, K. D., 2008: Hypothyroidism and obesity. Cause or effect? Saudi Med. J., 29, 1135-1138.

52. Weiss, R., Dziura, J., Burgert, T.S., Tamborlane, W.V., Taksali, S.E., Yeckel, S., 2004: Obesity and the metabolic syndrome in children and adolescents. N. Engl. J. Med., 350, 2362-2374.

53. Yelich, J. V., Wetteman, R.P., Dolewal, H.G., Lusby, K.S., Bishop, D. K., Spicer, L. J., 1995: Effects of growth rate on carcass composition and lipid partitioning at puberty and growth hormone, insulin-like factor I, insulin, and metabolites before puberty in beef heifers. J. Anim. Sci., 73, 2390—405.

Received November 9, 2016

Accepted January 16, 2016 